\title{
What Influences Customer's Trust on Online Social Network Sites (SNSs) Sellers?
}

\author{
Ramona Ramli ${ }^{1}$, Asmidar Abu Bakar ${ }^{2}$, Fiza Abdul Rahim ${ }^{3}$ \\ College of Computing and Informatics, Universiti Tenaga Nasional, Malaysia ${ }^{1,2}$ \\ Razak Faculty of Technology and Informatics, Universiti Teknologi Malaysia, Malaysia ${ }^{3}$ \\ Institute of Informatics and Computing Energy, Universiti Tenaga Nasional, Malaysia ${ }^{1,2,3}$
}

\begin{abstract}
Customer trust has been recognized as an essential part of the rising trend of social commerce. Lack of trust facilitates the hesitation of customers to shop online or to avoid them completely. Therefore, it is essential to implement and analyze a way of buyer-seller relationship establishment that will improve customers' trust. This paper aims to develop a trust model of Social Network Sites (SNSs) sellers, and to assess the dimensions and criteria that affects customer's trust on Online Social Network Sites (SNSs) sellers by using Analytic Hierarchy Process (AHP) approach. The study was carried out among those who have transactions with Malaysian online SNSs sellers at least every three months. The findings have indicated the top three influencing criteria: recommendation, transaction safety, and rating. This study provides insight into the customers' thoughts about placing trust on online SNSs sellers for selling and purchasing activities.
\end{abstract}

Keywords-Online commerce; trust; social commerce; multicriteria decision-making

\section{INTRODUCTION}

The emergence of social commerce on Social Network Sites (SNSs) has changed the near-constant connectivity that enables online sellers to connect with customers. Its 24/7 connectivity allows online SNSs sellers to produce their content and exchange products or services with other users. On the other side, the customer may connect with other online SNSs sellers for current information on products or services [1]. Various platforms are used to share information about products and services to increase sales volume [2] to build customer's trust in buying and purchasing activities.

Although social commerce has become widespread, certain challenges lead to the lack of trust among customers on online SNSs sellers. In social commerce, trust is referred to a customer's belief to trust a seller's ability, generosity, integrity, and predictableness [3]. The uncertainty of the level of content provided by users and the lack of face-to-face interactions make trust a crucial component of social commerce [4]. Social interactions between customers are believed to increase customer trust in sellers [5]. Many customers avoid making online purchases due to a lack of trust in online platforms [6]. For example, customers' concerns regarding the quality of the information provided by online SNSs sellers make them trust the information provided by other customers more than they trust the online SNSs sellers. This demonstrates the significance of trust in motivating people to purchase online.
Various studies were carried out to identify different criteria that influence customer's trust on purchase intention in social commerce. In [3], various characteristics influencing customers' trust in social commerce include reputation, size, information quality, transaction safety, communication, economic feasibility, and electronic word-of-mouth (E-WoM) referrals. Another study adopted some constructs from the technology acceptance model (TAM) to describe social commerce constructs [4], and show trust positively affects the purchase intention, consistent with many other TAM researches.

Trust and informativeness are suggested in [7] as social network characteristics that affect trust in social commerce. Analysis among Indonesia backpackers discovered that attitude and compatibility are significantly influenced purchase intention [8]. According to the research findings of young people's trust in tourism sites, trust and satisfaction are more important than site design and E-WoM [9]. A recent study in [10] indicates that trust and satisfaction influence repurchase and E-WoM intentions.

Several studies also examine the influencing criteria by concentrating on particular SNSs as the medium of social commerce. A study in [11] discovered that propensity to trust and testimonial were two factors that influence trust in the online purchase through SNSs. Results from a study conducted in Thailand, users of social commerce are more likely to trust social commerce if it provides adequate online environments that include recommendation and referrals, rating and reviews, communication, security issues and E-WoM [12].

An empirical study on Instagram users discovered that perceived benevolence, perceived integrity of online store and key opinion leader endorsement are significant factors explaining customer trust and later influencing purchase intention [13]. In a recent study examining the relationship between social presence and customer relationship quality as measured by customer commitment and loyalty, it was found that in social commerce, social commerce trust mediates the effect of social presence on both commitment and loyalty of customers [14]. A survey among individuals using social commerce services in Korea revealed four factors that influence purchase intention related to social commerce: economy, necessity, reliability and sales promotion [15]. A quantitative method depending upon the sample size is employed in most of the existing studies. On the other hand, 
one study finds the criteria through statistical methods and uses BP Neural Network approach to construct a social commerce trust evaluation model [16].

The trust element in purchasing-related decision-making can be seen as a multi-criteria decision-making (MCDM) problem. Problems are formulated and solved in MCDM with the criteria taken into consideration to assess an alternative's performance [17]. Analytic Hierarchy Process (AHP) is an MCDM approach that integrates quantitative and qualitative techniques [18] for handling measurable and intangible criteria. AHP enables subjective evaluation by using experts' judgement to decide the importance of criteria. Based on its importance, AHP determines the criteria that dominate the decision-making process and prioritize them. In decision-making, AHP reflects the analytical thinking of humans, where the assessment is performed in a hierarchical structure. In addition, all criteria to be taken into account will not be viewed as equal but by relative weight in the decision-making process. AHP decreases bias in the decision-making process by consistently reviewing the experts' evaluations.

This paper presents a study that aims to capture additional aspects of social commerce that supplement customers' insight and also encourage them to evaluate online SNSs sellers relatively. The rationale behind this study is to explore in-depth the factors that influence customers' trust. A sample of customers who have transactions with the identified Malaysian online SNSs sellers at least every three months is selected for experimental evaluation. This study also examined the potential of applying the AHP technique achieve two objectives:
1) to rank the criteria based on expert evaluation under multiple criteria relevant to this field.

2) to obtain the criteria weights by performing pairwise comparisons of importance between the criteria that influence customers' trust on online SNSs sellers and prioritize the influencing criteria prior to purchasing.

\section{DATA AND METHODOLOGY}

We proposed a research model for analyzing customers' trust focused on Malaysian society to evaluate online SNSs prior to buying-selling activities. The model is designed to analyze the relevant factors that influence Malaysian customers' trust in order to validate the buyer-seller relationships, especially in the field of SNSs. The primary goal of this empirical research was to determine whether and how customers' trust on online SNSs sellers is obtained before deciding to purchase. The AHP method used in this study is illustrated in Fig. 1 to investigate the criteria that affect the customers' trust in online SNSs sellers.

In this first step, the decision problem should be defined since it drives the whole process on why AHP has to be used. As the traditional rating method is unable to filter out the responses' inconsistency, the AHP methodology employs the consistency test that screen out inconsistent responses. This study identified criteria based on the previous literature, as shown in Table I [19]. These criteria would be expected to collect the necessary information regarding their buying decision for evaluations and comparisons.

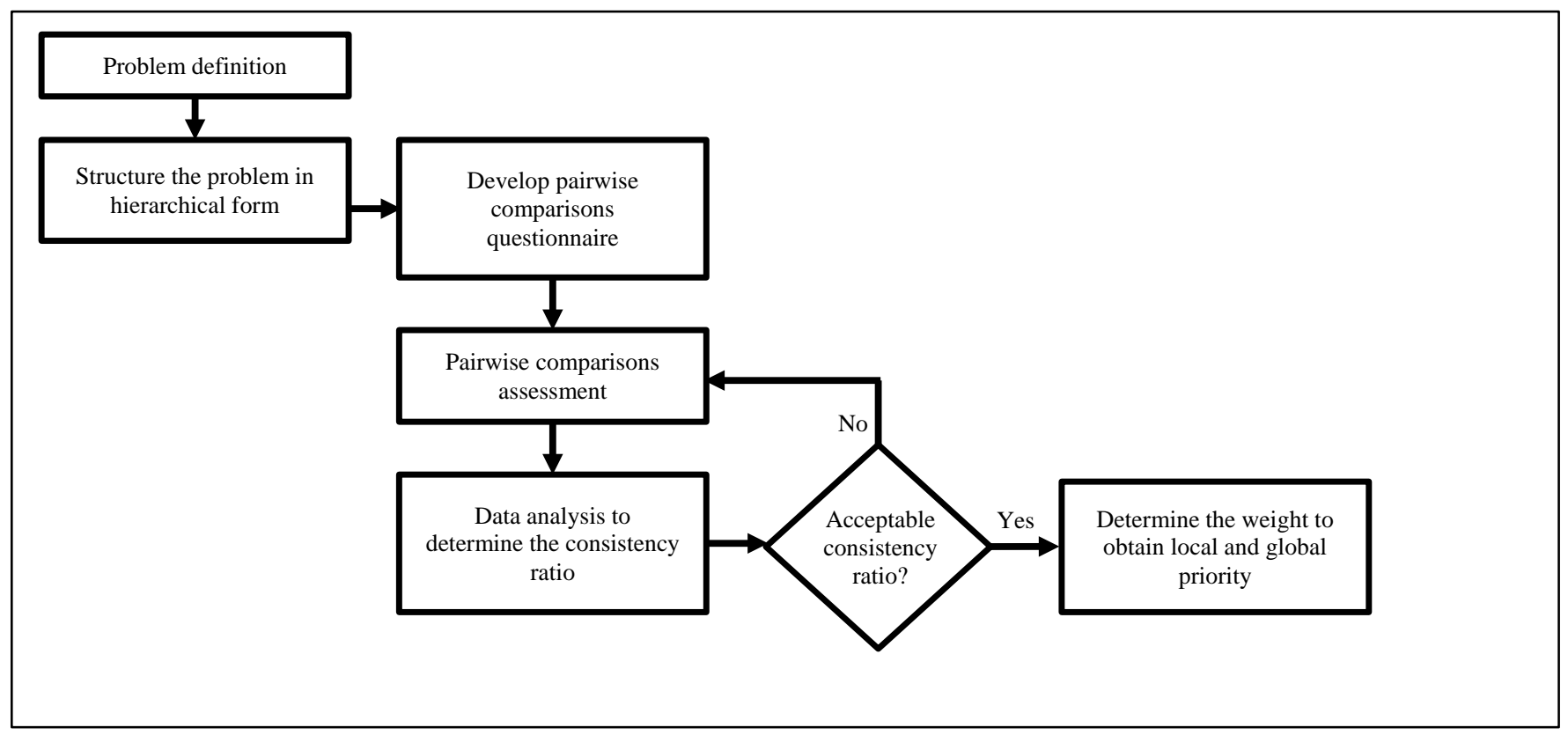

Fig. 1. Overview of AHP Methodology. 
TABLE I. PROBLEM IDENTIFICATION

\begin{tabular}{|c|c|c|}
\hline Dimension & Criteria & References \\
\hline \multirow{3}{*}{ E-WoM } & - $\quad$ Positive Valence & \multirow{2}{*}{ [3], [4], [20]-[25] } \\
\hline & - $\quad$ Negative Valence & \\
\hline & - $\quad$ E-WoM Content & [24], [26]-[29] \\
\hline \multirow{6}{*}{ Information Quality } & - $\quad$ Accuracy & [3], [30]-[33] \\
\hline & - $\quad$ Relevance & [30], [32], [33] \\
\hline & - $\quad$ Completeness & [3], [30]-[34] \\
\hline & - $\quad$ Currency & [3], [30]-[33] \\
\hline & - $\quad$ Understandability & [3], [30] \\
\hline & - $\quad$ Format & {$[30]-[33]$} \\
\hline \multirow{2}{*}{ Social Commerce Constructs } & - $\quad$ Recommendation & [4], [11], [34] \\
\hline & - $\quad$ Rating & [4], [34] \\
\hline \multirow{3}{*}{ People } & - $\quad$ Transaction Safety & [3], [22], [34] \\
\hline & - $\quad$ Reputation & [3], [34] \\
\hline & - $\quad$ Propensity to Trust & {$[22],[34]$} \\
\hline
\end{tabular}

\section{RESUltS}

A schematic representation in a hierarchical structure was formed to structure the problem, as illustrated in Fig. 2. The hierarchy consists of two levels and starts from Level 1 represents the goal, i.e. prioritizing the criteria to evaluate trust on online SNSs sellers. It is then broken up into four dimensions relevant to the goal are represented in Level 2: EWoM, information quality, social commerce constructs, and people. The sub-criteria associated with each of the dimensions form Level 3.
Once the hierarchical structure has been developed, the relative contribution of each criterion must be obtained through a paired comparison from each expert. In the AHP procedure, the selection of expertise is crucial in establishing the significance of factors in pair comparisons. It is thus vital to identify before a decision has been reached which criteria an expert has to satisfy [35]. Wrong expert selection may lead to a discrepancy in judgement. Furthermore, the qualities required by an expert are varied according to the field of study.

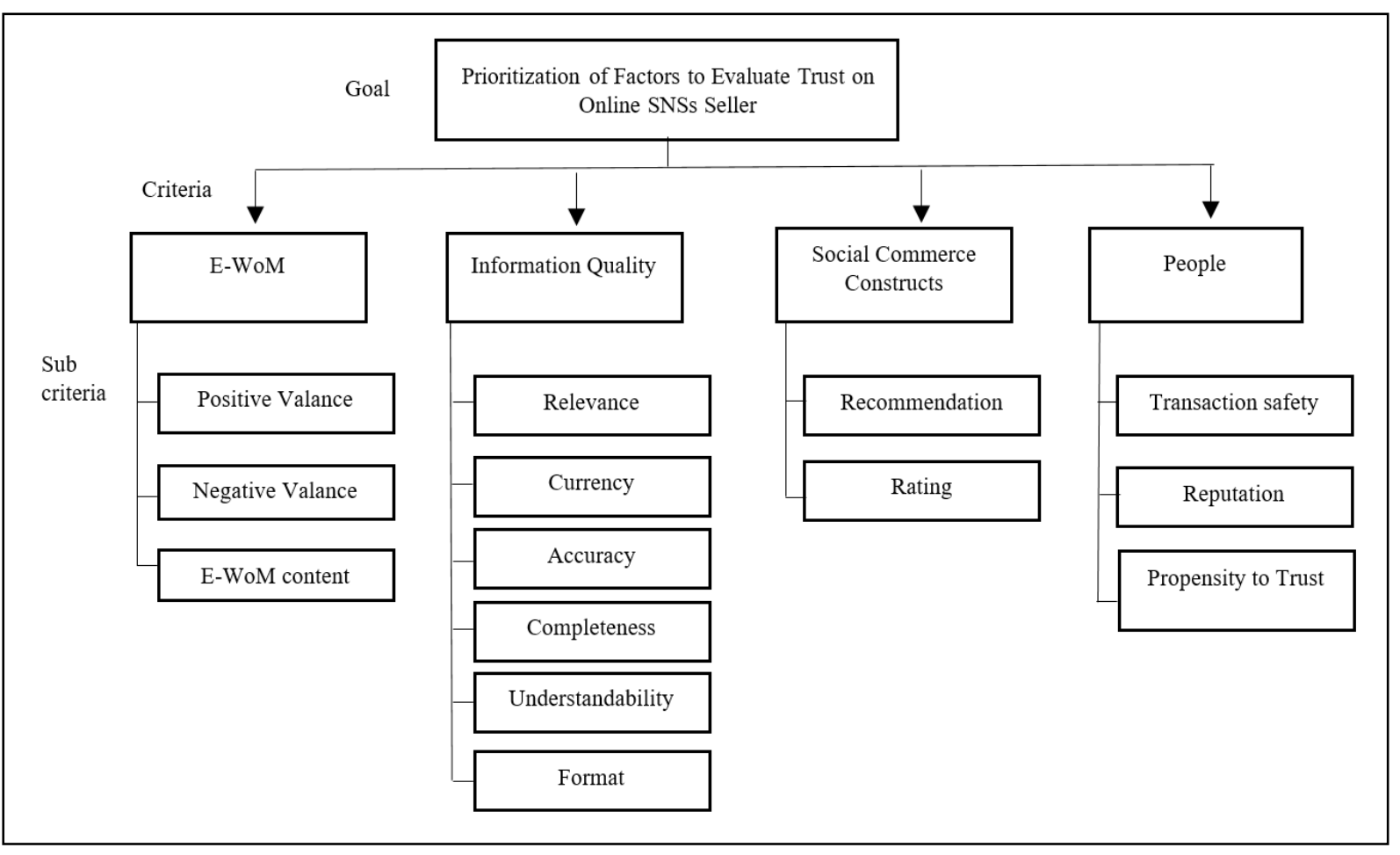

Fig. 2. Hierarchical Structure. 
The experts' input plays a significant role in getting the comparison pairwise. In the AHP technique, a single expert is usually assumed to be appropriate to offer a decision. However, a single expert can provide an uncertain judgment. To reduce the uncertain judgment, group decision-making can be employed. The judgment of each member is combined to reach a consensus in group decision-making.

According to Forman and Peniwati [36], two common approaches to aggregate the individual judgments are Aggregation of Individual Judgments (AIJ) and Aggregation of Individual Priorities (AIP). The AIJ combines all individual judgements to act as a 'new' decision by employing geometric mean. The AIP judgment, meanwhile, is based on a number of consensus groups, which may use either arithmetic or geometric mean. All other group decisions are added to the calculated group decisions.

In this study, experts are categorized as people who shop at least once every three months. The definition of experts is based on previously completed similar studies [3], [37]-[42]. 15 respondents took part in making a paired comparison based on the definition of experts, and this can be an excellent contribution to producing a less biased decision.

In order to identify the ranking among factors according to their importance, the information acquired from the questionnaire has been evaluated. The judgement was then consolidated to determine the weight of each criterion by each expert. Criterion ranking was based on the weight determined using the normalized principal Eigen criteria.

The results of this study were based on the evaluations made by the 15 respondents, which were then aggregated using the geometric mean as the AIJ approach was employed. Table II shows a sample of individual evaluations in the form of a pairwise comparison matrix.

The aggregate comparison matrix for criteria for the hierarchical structure level 2 is shown in Table III. An aggregate comparison matrix for sub-criteria in Level 3 to show the relative priorities of the sub-criteria with respect to the Criteria in Level 2 is shown in Table IV (sub-criteria EWoM), Table V (sub-criteria People), Table VI (sub-criteria Information Quality), and Table VII (sub-criteria Social Commerce Constructs).

TABLE II. SAMPLE INDIVIDUAL JUdGMENT IN THE PAIR-WISE COMPARISON MATRIX

\begin{tabular}{|c|c|c|c|c|c|c|}
\hline & 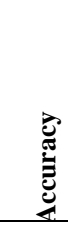 & 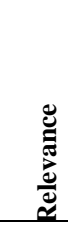 & 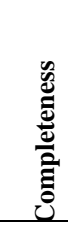 & 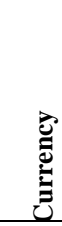 & 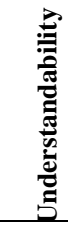 & \\
\hline Accuracy & 1 & 1 & 2 & $1 / 2$ & 1 & 3 \\
\hline Relevance & 1 & 1 & 1 & 1 & 2 & 5 \\
\hline Completeness & $1 / 2$ & 1 & 1 & $1 / 3$ & 2 & 3 \\
\hline Currency & 2 & 1 & 3 & 1 & 4 & 6 \\
\hline Understandability & 1 & $1 / 2$ & $1 / 2$ & $1 / 4$ & 1 & 1 \\
\hline Format & $1 / 3$ & $1 / 5$ & $1 / 3$ & $1 / 6$ & 1 & 1 \\
\hline
\end{tabular}

TABLE III. AGGREGATED COMPARISON MATRIX FOR CRITERIA

\begin{tabular}{|l|l|l|l|l|}
\hline & E-WoM & $\begin{array}{l}\text { Social } \\
\text { Commerce }\end{array}$ & $\begin{array}{l}\text { Information } \\
\text { Quality }\end{array}$ & People \\
\hline E-WoM & 1 & 0.89 & 1.07 & 0.94 \\
\hline $\begin{array}{l}\text { Social } \\
\text { Commerce }\end{array}$ & 1.12 & 1 & 1.25 & 0.94 \\
\hline $\begin{array}{l}\text { Information } \\
\text { Quality }\end{array}$ & 0.93 & 0.8 & 1 & 0.74 \\
\hline People & 1.06 & 1.06 & 1.35 & 1 \\
\hline
\end{tabular}

TABLE IV. AGgREgATED COMPARISON MATRIX FOR SUB-CRITERIA EWOM

\begin{tabular}{|l|l|l|l|}
\hline & $\begin{array}{l}\text { Positive } \\
\text { Valence }\end{array}$ & $\begin{array}{l}\text { Negative } \\
\text { Valence }\end{array}$ & $\begin{array}{l}\text { E-WoM } \\
\text { Content }\end{array}$ \\
\hline Positive Valence & 1 & 0.90 & 1.10 \\
\hline $\begin{array}{l}\text { Negative } \\
\text { Valence }\end{array}$ & 1.11 & 1 & 1.31 \\
\hline E-WoM Content & 0.91 & 0.76 & 1 \\
\hline
\end{tabular}

TABLE V. AgGRegated COMPARISON MAtRIX FOR SUB-CRITERIA PEOPLE

\begin{tabular}{|l|l|l|l|}
\hline & $\begin{array}{l}\text { Transaction } \\
\text { Safety }\end{array}$ & Reputation & $\begin{array}{l}\text { Propensity to } \\
\text { Trust }\end{array}$ \\
\hline $\begin{array}{l}\text { Transaction } \\
\text { Safety }\end{array}$ & 1 & 1.33 & 1.33 \\
\hline Reputation & 0.75 & 1 & 0.99 \\
\hline $\begin{array}{l}\text { Propensity to } \\
\text { Trust }\end{array}$ & 0.75 & 1.01 & 1 \\
\hline
\end{tabular}

TABLE VI. AGgREgATED COMPARISON MATRIX FOR SUB-CRITERIA INFORMATION QUALITY

\begin{tabular}{|c|c|c|c|c|c|c|}
\hline & 冚 & 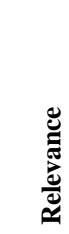 & ن & D & 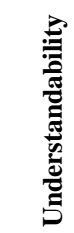 & 롤 \\
\hline Accuracy & 1 & 1.68 & 1.48 & 1.02 & 0.89 & 1.13 \\
\hline Relevance & 0.60 & 1 & 0.72 & 0.95 & 0.89 & 1.03 \\
\hline Completeness & 0.68 & 1.39 & 1 & 0.97 & 0.95 & 1.20 \\
\hline Currency & 0.98 & 1.05 & 1.03 & 1 & 1.03 & 1.37 \\
\hline Understandability & 1.13 & 1.13 & 1.05 & 0.97 & 1 & 1.28 \\
\hline Format & 0.88 & 0.97 & 0.83 & 0.73 & 0.78 & 1 \\
\hline
\end{tabular}

TABLE VII. AGGREGATED COMPARISON MATRIX FOR SUB-CRITERIA SOCIAL COMMERCE CONSTRUCTS

\begin{tabular}{|l|l|l|}
\hline & Recommendation & Rating \\
\hline Recommendation & 1 & 1.79 \\
\hline Rating & 0.56 & 1 \\
\hline
\end{tabular}

The pairwise comparisons were established for the criteria based on the judgements provided by each expert. The assessment will identify the importance of criteria and sub- 
criteria based on the hierarchy structure from step 2. The comparisons are made using a scale of absolute judgements that represents how much one element dominates another with respect to a given attribute.

In determining weights for criteria and sub-criteria, the following procedures are applied to each of the aggregated comparison matrices:

1) Calculate the sum values in each matrix column.

2) Divide each value in each column by the column sum to normalize the matrix.

3) Determine the weight by calculating the average value of each row of the normalized matrix.

The data is analyzed at this point in order to calculate the consistency ratio. If the consistency ratio is not acceptable, the pairwise comparison assessment will be reviewed by experts.

When it comes to making decisions, humans are notoriously inconsistent. The Consistency Ratio (CR) measures the consistency of judgments in order to validate the results. The acceptable CR values (Table VIII) depend on the size of matrices as proposed in [43]. The judgments are consistent and valid if the value is within the range. In this scenario, the experts will be requested to review their judgement. Because of the equation's constraint, the CR value is not relevant to $2 \mathrm{X} 2$ matrices [42]. In addition, the two-element matrix has a perfect consistency.

The following four steps are used to compute the CR:

1) Multiply each column total by its respective weight for each criteria.

2) Get the $\lambda \max$ value by adding values calculated in Step 1. (1).

3) Get the Consistency Index (CI) value using Equation

$\mathrm{CI}=\left(\lambda_{\max }-\mathrm{n}\right) /(\mathrm{n}-1)$

where $n$ is the number of the criteria being compared in the matrix.

4) Get the CR value using Equation (2).

$\mathrm{CR}=\mathrm{CI} / \mathrm{RI}$

where RI is the Random Index. RI value is determined from a lookup table (Table IX) depends on the $\mathrm{n}$ value.

TABLE VIII. ACCEPTABLE CR VALUE

\begin{tabular}{|l|l|}
\hline Size of matrices & Acceptable CR values \\
\hline $2 \times 2$ & Not applicable \\
\hline $3 \times 3$ & $\leq 5 \%$ \\
\hline $4 \times 4$ & $\leq 8 \%$ \\
\hline Larger & $\leq 10 \%$ \\
\hline
\end{tabular}

TABLE IX. RANDOM INDEX

\begin{tabular}{|l|l|l|l|l|l|l|l|l|l|l|}
\hline $\mathbf{n}$ & $\mathbf{1}$ & $\mathbf{2}$ & $\mathbf{3}$ & $\mathbf{4}$ & $\mathbf{5}$ & $\mathbf{6}$ & $\mathbf{7}$ & $\mathbf{8}$ & $\mathbf{9}$ & $\mathbf{1 0}$ \\
\hline $\mathrm{R}$ & 0.0 & 0.0 & 0.5 & 0.9 & 1.1 & 1.2 & 1.3 & 1.4 & 1.4 & 1.4 \\
$\mathrm{I}$ & 0 & 0 & 8 & 0 & 2 & 4 & 2 & 1 & 5 & 9 \\
\hline
\end{tabular}

\section{DISCUSSION}

This section discusses the data analysis for the criteria and each sub-criteria, as well as the determination of weight to obtain local and global priority.

\section{A. Criteria}

People are the most significant criteria, as demonstrated in Table X, with a weight of $28 \%$. Individuals, small or large groups of people, or communities who play a key role in social commerce are referred to as individual consumers and sellers [44].

With a weight of $27 \%$, Social Commerce Constructs is ranked second. Customers can create their own content and share their experiences with online SNSs vendors, products, or services using features offered on social platforms. At the same time, they are permitted to exchange information with others and to offer online social support to other customers. According to [45], social commerce constructs have an impact on customers' trust as well as purchase intention.

In the ranking, E-WoM comes in third. Customers rely on information offered by others to assist them in making purchasing decisions in a virtual world of social commerce. Customers must share any information written by them in order to build confidence with online SNSs sellers.

The Information Quality is ranked last. The customer's absence of direct product experience necessitates adequate, reliable, and high-quality information offered by online SNSs sellers. In addition, the transaction takes place in a non-face-toface setting.

\section{B. Sub-Criteria for E-WoM}

The ranking of sub-criteria under E-WoM criteria is shown in Table XI. With a weight of 38\%, negative valence takes first rank. This is reinforced by a study conducted by [46] which found that negative valence e-WoM had a greater impact on client decision-making than positive valence e-WoM. Positive valence, on the other hand, comes in second rank with a weight of $33 \%$. With a weight of 29 percent, e-WoM material is ranked last. Customers who are heavily involved in online purchases are influenced by the quality of e-WoM, whereas those who are less involved are influenced by the volume of eWoM [47].

\section{Sub-Criteria for People}

The ranking of sub-criteria evaluated under the People criteria is shown in Table XII. With a weight of $40 \%$, Transaction Safety is at the top of the list. Account transfers or bank deposits are the most prevalent payment methods used by customers and online SNSs sellers in social commerce. It is critical for a customer to believe that the seller is protecting their personal and transaction information through this process.

With weights of $30 \%$, Reputation is ranked second. Customers assume that the seller of online SNSs is skilled and trustworthy based on their reputation. Customers will trust online SNSs sellers that have a strong reputation in their buying and selling activities. 
TABLE X. NORMALIZED MATRIX AND RANKING WEIGHTS OF CRITERIA

\begin{tabular}{|c|c|c|c|c|c|c|c|c|}
\hline Criteria & E-WoM & $\begin{array}{l}\text { Social Commerce } \\
\text { Constructs }\end{array}$ & $\begin{array}{l}\text { Information } \\
\text { Quality }\end{array}$ & People & Weights & $\square_{\max }, \mathbf{C I}, \mathbf{R I}$ & CR & Ranking \\
\hline E-WoM & 0.243 & 0.237 & 0.229 & 0.260 & 0.242 & \multirow{4}{*}{$\begin{array}{l}\square \text { max }=4.0028 \\
\mathrm{CI}=0.0009 \\
\mathrm{RI}=0.9\end{array}$} & \multirow{4}{*}{0.0010} & 3 \\
\hline $\begin{array}{l}\text { Social } \\
\text { Commerce } \\
\text { Constructs }\end{array}$ & 0.273 & 0.266 & 0.268 & 0.260 & 0.267 & & & 2 \\
\hline $\begin{array}{l}\text { Information } \\
\text { Quality }\end{array}$ & 0.227 & 0.213 & 0.214 & 0.204 & 0.215 & & & 4 \\
\hline People & 0.258 & 0.283 & 0.289 & 0.276 & 0.277 & & & 1 \\
\hline
\end{tabular}

TABLE XI. NORMALIZED MATRIX AND RANKING WEIGHTS OF SUB-CRITERIA E-WOM

\begin{tabular}{|c|c|c|c|c|c|c|c|}
\hline Sub-criteria & Positive Valence & Negative Valence & E-WoM Content & Weights & $\lambda_{\max }, \mathbf{C I}, \mathbf{R I}$ & CR & Ranking \\
\hline Positive Valence & 0.331 & 0.338 & 0.323 & 0.331 & \multirow{3}{*}{$\begin{array}{l}\lambda_{\text {max }}=3.000 \\
\mathrm{CI}=0.0002 \\
\mathrm{RI}=0.58\end{array}$} & \multirow{3}{*}{0.0004} & 2 \\
\hline Negative Valence & 0.368 & 0.375 & 0.384 & 0.376 & & & 1 \\
\hline E-WoM Content & 0.301 & 0.287 & 0.293 & 0.294 & & & 3 \\
\hline
\end{tabular}

TABLE XII. Normalized Matrix AND RANKIng Weights of Sub-Criteria People

\begin{tabular}{|c|c|c|c|c|c|c|c|}
\hline Sub-criteria & Transaction Safety & Reputation & Propensity to Trust & Weights & $\lambda_{\max }, \mathbf{C I}, \mathbf{R I}$ & CR & Ranking \\
\hline Transaction Safety & 0.399 & 0.398 & 0.401 & 0.399 & \multirow{3}{*}{$\begin{array}{l}\lambda_{\max }=3.000 \\
\mathrm{CI}=5.72 \mathrm{E}-06 \\
\mathrm{RI}=0.58\end{array}$} & \multirow{3}{*}{$9.86 \mathrm{E}-06$} & 1 \\
\hline Reputation & 0.300 & 0.299 & 0.298 & 0.299 & & & 3 \\
\hline Propensity to Trust & 0.300 & 0.302 & 0.301 & 0.301 & & & 2 \\
\hline
\end{tabular}

TABLE XIII. NORMALIZED MATRIX AND RANKING WEIGHTS OF SUB-CRITERIA INFORMATION QUALITY

\begin{tabular}{|c|c|c|c|c|c|c|c|c|c|c|}
\hline Sub-criteria & Accuracy & Relevance & Completeness & Currency & Understandability & Format & Weights & $\begin{array}{l}\lambda_{\max }, \\
\text { CI,RI }\end{array}$ & CR & Ranking \\
\hline Accuracy & 0.190 & 0.233 & 0.242 & 0.181 & 0.161 & 0.161 & 0.195 & \multirow{6}{*}{$\begin{array}{l}\lambda_{\max } \\
=6.0444 \\
\mathrm{CI}= \\
0.0088 \\
\mathrm{RI}=1.24\end{array}$} & \multirow{6}{*}{0.0071} & 1 \\
\hline Relevance & 0.113 & 0.139 & 0.118 & 0.168 & 0.161 & 0.147 & 0.141 & & & 5 \\
\hline Completeness & 0.128 & 0.192 & 0.163 & 0.172 & 0.171 & 0.171 & 0.167 & & & 4 \\
\hline Currency & 0.186 & 0.146 & 0.169 & 0.177 & 0.186 & 0.195 & 0.177 & & & 2 \\
\hline Understandability & 0.214 & 0.156 & 0.172 & 0.172 & 0.180 & 0.183 & 0.179 & & & 3 \\
\hline Format & 0.168 & 0.135 & 0.136 & 0.129 & 0.141 & 0.143 & 0.142 & & & 6 \\
\hline
\end{tabular}

TABLE XIV. NORMALIZED MATRIX AND RANKING WEIGHTS OF SUB-CRITERIA SOCIAL COMMERCE CONSTRUCTS

\begin{tabular}{|c|c|c|c|c|c|c|}
\hline & Recommendation & Rating & Weights & $\lambda_{\max }, \mathbf{C I}, \mathbf{R I}$ & CR & Ranking \\
\hline Recommendation & 0.642 & 0.642 & 0.642 & $\begin{array}{l}\lambda=2 \\
\mathrm{CI}=0 \\
\mathrm{RI}=0\end{array}$ & \multirow[t]{2}{*}{ NA } & 1 \\
\hline Rating & 0.358 & 0.358 & 0.358 & 0.168 & & 2 \\
\hline
\end{tabular}

Propensity is ranked last, with a weight value of the same as Reputation. Since customers and sellers may or may not know each other, trust plays a vital part in social commerce. As a result, each person's level of trust may vary depending on the information available.

\section{Sub-Criteria for Information Quality}

In social commerce, information quality has been identified as a significant criterion in influencing customers' online purchase decisions [48]. The ranking of sub-criteria evaluated under the Information Quality criteria is shown in Table XIII. With a weight of 19 percent, Accuracy is ranked top. Customers may be forced to rely on the information provided by the seller if they are unable to test the product or services prior to making a purchase. As a result, sellers must be able to deliver information that is accurate, unambiguous, meaningful, believable, and consistent.

With the same weight of 18 percent, Currency and Understandability are ranked second and third. Sellers must present up-to-date information that customers can grasp in order to gain their trust. With a weight of 17 percent, Completeness is ranked fourth. Relevance and Format, meanwhile, are ranked fifth and sixth, respectively, with a 14 percent weighting. The seller's information should represent all conceivable states that are relevant and required by the user when making a purchase choice. 


\section{E. Sub-Criteria for Social Commerce Constructs}

The ranking of sub-criteria studied under Social Commerce Constructs criteria is shown in Table XIV. Recommendation is ranked first, with a 64 percent weighting. With a weight of $36 \%$, a Rating that represents a measurement scale on a product, service, or seller is ranked second. Customers must rely on other customers' experiences represented through ratings and recommendations because they cannot personally experience the product or services.

\section{F. Determination of Local and Global Weights}

The weights for each primary criteria are multiplied by the weights of each relevant sub-criteria to arrive at the global weights. Local weights are the weights assigned to each main and sub-criteria. Table XV reveals that the sub-criteria Social Commerce Constructs' (0.1728) is the most important, followed by Transaction Safety (0.1120) under sub-criteria People. The least important sub-criteria, Relevance and Format of Information Quality, are both weighted at 0.0294 .

This study identified new criteria and sub-criteria for evaluating the trustworthiness of online SNSs sellers from a theoretical standpoint. To depict the priority of characteristics that influence customers' trust in those sellers, a hierarchy structural model is built as illustrated in Fig. 3.

Online SNSs sellers can use the identified influencing criteria to improve their business activity in the real world. One of the most important findings is that online SNSs sellers should pay more attention to customer recommendations, which could lead to increased client trust. Existing customers' positive recommendations may entice new consumers to engage in buying-selling activities. Furthermore, if a known friend recommends an online SNSs sellers, potential clients will have more confidence in the business.

Second, throughout the selling-buying activities, online SNSs sellers must verify that the transaction and its linked information are secure. For transaction payment, the majority of online SNSs sellers employ bank transfers. As a result, it is critical to ensure that the personal information of associated customers is kept secure and not shared with third parties. Customers should also be constantly updated about transaction status and payment confirmation because the transaction does not take place face-to-face.

Finally, customers can use ratings to help them decide whether or not to purchase something. Existing customers rate online SNSs sellers based on their transaction experience. Because a positive rating will help potential clients trust online SNSs sellers, online SNSs sellers must maintain a positive rating in order to expand their business. In addition, customers' trust in online SNS sellers should be based on the People dimension and Social Commerce Constructs as discussed in the analysis results.

TABLE XV. FINAL WEIGHTS AND OVERALl RANKING - GRAPH

\begin{tabular}{|c|c|c|c|c|c|}
\hline Criteria & Local Weights & Sub-criteria & Local Weights & Global Weights & Overall Ranks \\
\hline \multirow{3}{*}{ E-WoM } & \multirow{3}{*}{0.240} & Positive Valence & $33 \%$ & $7.92 \%$ & 7 \\
\hline & & Negative Valence & $38 \%$ & $9.12 \%$ & 4 \\
\hline & & E-WoM Content & $29 \%$ & $6.96 \%$ & 8 \\
\hline \multirow{2}{*}{ Social Commerce Constructs } & \multirow{2}{*}{$27 \%$} & Recommendation & $64 \%$ & $17.28 \%$ & 1 \\
\hline & & Rating & $36 \%$ & $9.72 \%$ & 3 \\
\hline \multirow{6}{*}{ Information Quality } & \multirow{6}{*}{$21 \%$} & Accuracy & $19 \%$ & $3.99 \%$ & 9 \\
\hline & & Relevance & $14 \%$ & $2.94 \%$ & 13 \\
\hline & & Completeness & $17 \%$ & $3.57 \%$ & 12 \\
\hline & & Currency & $18 \%$ & $3.78 \%$ & 10 \\
\hline & & Understandability & $18 \%$ & $3.78 \%$ & 11 \\
\hline & & Format & $14 \%$ & $2.94 \%$ & 14 \\
\hline \multirow{3}{*}{ People } & \multirow{3}{*}{$28 \%$} & Transaction Safety & $40 \%$ & $11.20 \%$ & 2 \\
\hline & & Reputation & $30 \%$ & $8.40 \%$ & 6 \\
\hline & & Propensity to Trust & $30 \%$ & $8.40 \%$ & 5 \\
\hline
\end{tabular}




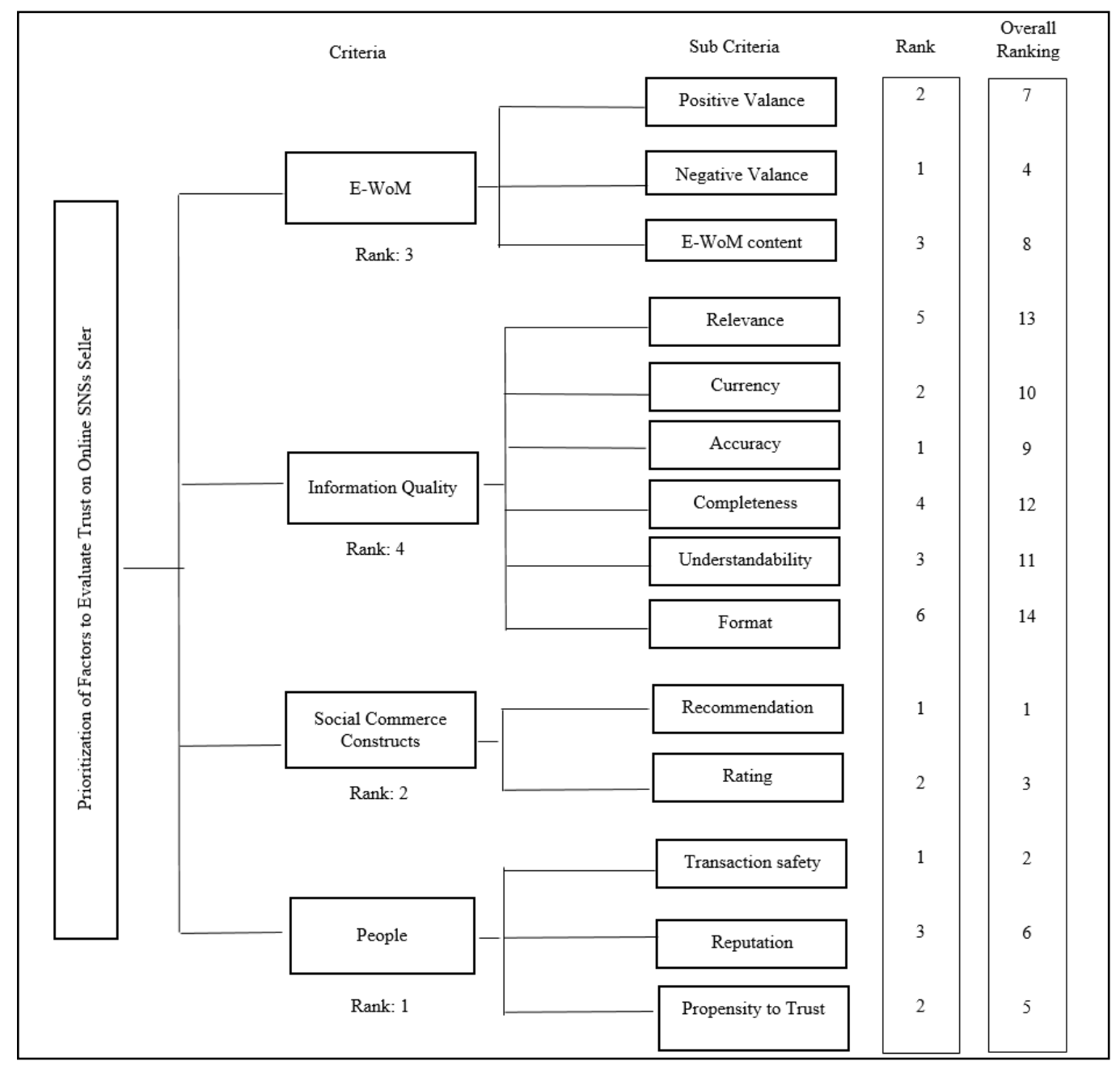

Fig. 3. Hierarchy Structure Model

\section{CONCLUSION}

Customers lack direct product experience in social commerce since activities take place in a non-face-to-face environment. A lot of research has been undertaken to investigate the factors that influence customers' trust in online commerce. However, there are few studies that look at the criteria and their significance in the context of online sellers who utilize social media sites as their marketing platforms. This study addresses the gap by examining the factors for boosting customers' trust in online SNSs sellers from many angles.

This study has successfully achieved the objective by using the AHP technique to discover and rank the criteria that influence a customer's trust in online SNSs sellers prior to making a purchase intention. The following criteria are prioritized based on the ranking: (1) Recommendation, (2) Transaction Safety, (3) Rating, (4) Negative Valence, and (5) Propensity to Trust, according to this study. To highlight the priority as well as the interaction between criteria and subcriteria, a hierarchy structural model is created.

The findings of this study show which criteria the customers should consider according to its importance when evaluating the reliability of online SNSs sellers prior to making a purchase. The identified criteria, on the other hand, will serve as a guideline for online SNSs sellers to establish customer trust in their buying and selling activities.

The identified criteria and sub-criteria can be investigated further in future research to quantitatively assess the trustworthiness of online SNSs sellers. There may be interrelationships between some of the specified criteria and sub-criteria. In that instance, Analytical Network Process (ANP) might be used to do more research because it ignores interaction between criteria and sub-criteria. The results of this study can be integrated or compared with those from other multi-criteria approaches like TOPSIS, ELECTRE, and SWOT.

\section{REFERENCES}

[1] T. Ric and D. Benazić, "From social interactivity to buying: an instagram user behaviour based on the S-O-R paradigm," Econ. Res. Istraživanja, vol. 0, no. 0, pp. 1-19, 2022, doi: 10.1080/1331677x.2021.2025124.

[2] L. Guan, H. Chen, H. Ma, and L. Zhang, "Optimal group-buying price strategy considering the information-sharing of the seller and buyers in social e-commerce," Int. Trans. Oper. Res., vol. 29, no. 3, pp. 17691790, May 2022, doi: https://doi.org/10.1111/itor.13075. 
[3] S. Kim and H. Park, "Effects of various characteristics of social commerce (s-commerce) on consumers' trust and trust performance," Int. J. Inf. Manage., vol. 33, no. 2, pp. 318-332, 2013, doi: 10.1016/j.ijinfomgt.2012.11.006.

[4] N. Hajli, "Social commerce constructs and consumer's intention to buy," Int. J. Inf. Manage., vol. 35, no. 2, pp. 183-191, Apr. 2015, doi: 10.1016/j.ijinfomgt.2014.12.005.

[5] M. N. Hajli, "A study of the impact of social media on consumers," Int. J. Mark. Res., vol. 56, no. 3, pp. 387-404, 2014, doi: 10.2501/UMR2014-025.

[6] G. A. Tran and D. Strutton, "Comparing email and SNS users: Investigating e-servicescape, customer reviews, trust, loyalty and EWOM,” J. Retail. Consum. Serv., vol. 53, no. March 2019, p. 101782, 2020, doi: 10.1016/j.jretconser.2019.03.009.

[7] M.-C. Han, "How Social Network Characteristics Affect Users' Trust and Purchase Intention,” Int. J. Bus. Manag., vol. 9, no. 8, Jul. 2014, doi: 10.5539/ijbm.v9n8p122.

[8] A. P. Aristio, S. Supardi, R. A. Hendrawan, and A. A. Hidayat, "Analysis on purchase intention of Indonesian backpacker in accommodation booking through online travel agent," Procedia Comput. Sci., vol. 161, pp. 885-893, 2019, doi: 10.1016/j.procs.2019.11.196.

[9] D. Buhalis, E. Parra López, and J. A. Martinez-Gonzalez, "Influence of young consumers' external and internal variables on their e-loyalty to tourism sites,” J. Destin. Mark. Manag., vol. 15, p. 100409, Mar. 2020, doi: 10.1016/j.jdmm.2020.100409.

[10] N. Meilatinova, "Social commerce: Factors affecting customer repurchase and word-of-mouth intentions,” Int. J. Inf. Manage., vol. 57, p. 102300, Apr. 2021, doi: 10.1016/j.ijinfomgt.2020.102300.

[11] K. M. Nor, W. N. Fazni Wan Mohamad Nazarie, and A. A.-A. Md Yusoff, "Factors influencing individuals' trust in online purchase through social networking sites,” 2013 7th Intenational Conf. eCommerce Dev. Ctries. With Focus e-Security, ECDC 2013, 2013, doi: 10.1109/ECDC.2013.6556752.

[12] C. Pothong and C. Sathitwiriyawong, "Factors of s-commerce influencing trust \& purchase intention,” 20th Int. Comput. Sci. Eng. Conf. Smart Ubiquitos Comput. Knowledge, ICSEC 2016, pp. 0-4, 2017, doi: 10.1109/ICSEC.2016.7859879.

[13] J. W. S. Che and C. M. K. Cheung, "Consumer Purchase Decision in Instagram Stores : The Role of Consumer Trust," pp. 24-33, 2017.

[14] W. Nadeem, A. H. Khani, C. D. Schultz, N. A. Adam, R. W. Attar, and N. Hajli, "How social presence drives commitment and loyalty with online brand communities? the role of social commerce trust," J. Retail. Consum. Serv., vol. 55, no. March, p. 102136, 2020, doi: 10.1016/j.jretconser.2020.102136.

[15] J. W. Sohn and J. K. Kim, "Factors that influence purchase intentions in social commerce,” Technol. Soc., vol. 63, p. 101365, Nov. 2020, doi: 10.1016/j.techsoc.2020.101365.

[16] L. Chen and R. Wang, "A Trust Evaluation Model for Social Commerce Based on BP Neural Network,” J. Data Anal. Inf. Process., vol. 04, no. 04, pp. 147-158, 2016, doi: 10.4236/jdaip.2016.44013.

[17] G. Pasi, M. Viviani, and A. Carton, “A Multi-Criteria Decision Making approach based on the Choquet integral for assessing the credibility of User-Generated Content,” Inf. Sci. (Ny)., vol. 503, pp. 574-588, Nov. 2019, doi: 10.1016/j.ins.2019.07.037.

[18] N. Bhushan and K. Rai, Strategic Decision Making: Applying the Analytic Hierarchy Process. London: Springer-Verlag London, 2004.

[19] R. Ramli, A. A. Bakar, and R. Ismail, "The Trust Effect Towards Online Seller in Social Commerce," Proc. 6th Int. Conf. Comput. Informatics, no. 030, pp. 317-322, 2017.

[20] T. Hennig-Thurau, K. P. Gwinner, G. Walsh, and D. D. Gremler, "Electronic word-of-mouth via consumer-opinion platforms: What motivates consumers to articulate themselves on the Internet?," J. Interact. Mark., vol. 18, no. 1, pp. 38-52, 2004, doi: 10.1002/dir.10073.

[21] A. Leerapong and A. Mardjo, "Trust and Risk in Purchase Intention through Online Social Network: A Focus Group Study of Facebook in Thailand,” Inf. Manag. Bus. Rev., vol. 5, no. 3, pp. 144-154, 2013, doi: 10.7763/JOEBM.2013.V1.68.
[22] A. D. Noor, R. Sulaiman, and A. A. Bakar, "A Review of Factors that Influenced Online Trust in Social Commerce,” Int. Conf. Inf. Technol. Multimed., pp. 118-123, 2014.

[23] C. S. P. Ng, "Intention to purchase on social commerce websites across cultures: A cross-regional study,” Inf. Manag., vol. 50, no. 8, pp. 609620, 2013, doi: 10.1016/j.im.2013.08.002.

[24] Y. Wang and C. Yu, "Social interaction-based consumer decisionmaking model in social commerce: The role of word of mouth and observational learning,” Int. J. Inf. Manage., vol. 37, no. 3, pp. 179-189, 2017, doi: 10.1016/j.ijinfomgt.2015.11.005.

[25] Y. Wang, S. Wang, Y. Fang, and P. Y. K. Chau, "Store survival in online marketplace: An empirical investigation,” Decis. Support Syst., vol. 56, no. 1, pp. 482-493, 2013, doi: 10.1016/j.dss.2012.11.005.

[26] T. Hennig-Thurau et al., "The Impact of New Media on Customer Relationships,” J. Serv. Res., vol. 13, no. 3, pp. 311-330, 2010, doi: 10.1177/1094670510375460.

[27] C. Lin, Y.-S. Wu, and J.-C. V. Chen, "Electronic Word-of-Mouth: The Moderating Roles of Product Involvement and Brand Image," Proc. 2013 Int. Conf. Technol. Innov. Ind. Manag., pp. 29-47, 2013.

[28] K. Vimaladevi, "A Study on the Effects of Online Consumer Reviews on Purchasing Decision,” Prestig. Int. J. Manag. IT-Sanchayan, vol. 1, no. 1, pp. 91-99, 2012.

[29] A P. a Yayli and I. M. Bayram, "eWOM: THE EFFECTS OF ONLINE CONSUMER REVIEWS ON PURCHASING DECISION OF ELECTRONIC GOODS,” Marketingtrendscongresscom, 2009.

[30] J. V. Chen, B. Su, and A. E. Widjaja, "Facebook C2C social commerce: A study of online impulse buying," Decis. Support Syst., vol. 83, pp. 57-69, Mar. 2016, doi: 10.1016/j.dss.2015.12.008.

[31] R. R. Nelson, P. A. Todd, and B. H. Wixom, "Antecedents of Information and System Quality: An Empirical Examination Within the Context of Data Warehousing,” J. Manag. Inf. Syst., vol. 21, no. 4, pp. 199-235, 2005, doi: 10.1362/026725705774538390.

[32] Y. Wand and R. Y. Wang, "Anchoring data quality dimensions in ontological foundations,” Commun. ACM, vol. 39, no. 11, pp. 86-95, Nov. 1996, doi: 10.1145/240455.240479.

[33] N. Au, E. W. T. Ngai, and T. C. E. Cheng, "Extending the Understanding of End User Information Systems Satisfaction Formation: An Equitable Needs Fulfillment Model Approach.,” MIS Q., vol. 32, no. 1, pp. 43-66, 2008, doi: 10.2307/25148828.

[34] A. A. Syuhada and W. Gambett, "Online Marketplace for Indonesian Micro Small and Medium Enterprises based on Social Media,” Procedia Technol., vol. 11, no. Iceei, pp. 446-454, 2013, doi: 10.1016/j.protcy.2013.12.214.

[35] R. Gawlik, M. Głuszak, and A. Małkowska, "The Measurement of Housing Preferences in the Analytic Hierarchy Process," Folia Oeconomica Stetin., vol. 17, no. 1, Jan. 2017, doi: 10.1515/foli-20170003.

[36] Ernest Forman and Kirti Peniwati, "Aggregating individual judgments and priorities with the Analytic Hierarchy Process,” Eur. J. Oper. Res., vol. 108, pp. 165-169, 1998.

[37] K. M. Nor, W. N. Fazni Wan Mohamad Nazarie, and A. A.-A. Md Yusoff, "Factors influencing individuals' trust in online purchase through social networking sites," in 7th International Conference on eCommerce in Developing Countries:with focus on e-Security, Apr. 2013, vol. 11, no. SPL.ISS., pp. 1-18, doi: 10.1109/ECDC.2013.6556752.

[38] S. Sukrat, B. Papasratorn, and V. Chongsuphajaisiddhi, "Impact of Customer Trust on Purchase Intention in Organic Rice through Facebook : A Pilot Study,” 10th Int. Conf. E-bus., 2015.

[39] Z. Zamrudi, I. Suyadi, and Y. Abdillah, "the Effect of Social Commerce Construct and Brand Image on Consumer Trust and Purchase Intention," Profit J. Adm. Bisnis, vol. 10, no. 1, pp. 1-13, 2016, doi: 10.9876/VOL1ISSN1978-743X.

[40] ASEAN UP, "Insights and trends of e-commerce in Malaysia - ASEAN UP,” 2017.

[41] N. A. Hashim, S. M. Nor, and H. Janor, "Riding the Waves of Social Commerce: An Empirical Study of Malaysian Entrepreneurs," Geogr. Online TM Malaysian J. Soc. Sp., vol. 2, no. 2, pp. 83-94, 2016. 
[42] M. Dashti, A. Sanayei, H. R. Dolatabadi, and M. H. Moshrefjavadi, “An Analysis of Factors Affecting Intention to Purchase Products and Services in Social Commerce,” Mod. Appl. Sci., vol. 10, no. 12, p. 98, 2016, doi: 10.5539/mas.v10n12p98.

[43] T. L. Saaty, "How to Make a Decision: The Analytic Hierarchy Process,” Interfaces (Providence)., 1994, doi: 10.1287/inte.24.6.19.

[44] C. Wang and P. Zhang, "The Evolution of Social Commerce: The People , Management , Technology , and Information Dimensions," 2012.

[45] N. Hajli and J. Sims, "Social commerce: The transfer of power from sellers to buyers," Technol. Forecast. Soc. Change, vol. 94, no. March, pp. 350-358, 2015, doi: 10.1016/j.techfore.2015.01.012.
[46] T. Hennig-Thurau and G. Walsh, "Electronic Word-of-Mouth: Motives for and Consequences of Reading Customer Articulations on the Internet,” ... J. Electron. Commer., vol. 8, no. 2, pp. 51-74, 2003, doi: 10.1504/IJECRM.2008.020411.

[47] S.-H. Lee, "How do online reviews affect purchasing intention?," African J. Bus. Manag., vol. 3, no. 10, pp. 576-581, 2009, doi: 10.5897/AJBM09.204.

[48] B. Shen, D. Liu, and L. Tai, "Customer Information Sharing in Social Commerce Based on FIRE Model: The Role of Trust Propensity,” 2014 Int. Conf. Manag. e-Commerce e-Government, pp. 119-123, 2014, doi: 10.1109/ICMeCG.2014.33. 